\title{
Retro Pazarlama Perspektifinden Tadım Kuruyemiş Markası İle İlgili Reklamın Göstergebilimsel Analiz Yöntemi İle İncelenmesi
}

\author{
Murat Toksarı (Doç. Dr. ) \\ iD Sivas Cumhuriyet Üniversitesi Illetişim Fakültesi
} mtoksari@cumhuriyet.edu.tr

Amine Feyzanur Aydar (Yüksek Lisans Öğrencisi)

Sivas Cumhuriyet Üniversitesi Sosyal Bilimler Enstitüsü

feyzanuraydar@gmail.com

Başvuru Tarihi: 23.03.2021

Yayına Kabul Tarihi: 28.06.2021

Yayınlanma Tarihi: 30.07.2021

https://doi.org/10.17680/erciyesiletisim.901504

\section{Öz}

Günümüzün rekabet dünyasında tüketicilerin zihinlerinde marka algısı oluşturmak isteyen her işletmenin, marka ile tüketici arasında güçlü bağ oluşturacak stratejiler geliştirmesi oldukça önemlidir. Markaların birbirini taklit ettiği, abartılı reklamların oldukça bol olduğu, verilmek istenen mesajdan çok tüketicileri eğlendirmeye yönelik reklamların çoğaldığı ve tüketici alışkanlıklarının değiştiği günümüz dünyasında doğru mesajı vermek çok önemlidir. Bu nedenlerle tüketiciler üzerinde duygusal bir etki bırakmak, geçmiş zevk alışkanlıklarından bazılarını hatırlatmak ve bunları markayla harmanlamak ve medya araçlarıyla sunmak, işletmeler için retro pazarlama kavramlarının önemini artırmıştır. Bu bağlamda işletmeler, tüketicilerin subliminal algılarında duygusal yoğunluğa sebebiyet veren mesaj içeriklerine yönelmişler ve retro pazarlamaya ağırlık veren stratejiler geliştirmişlerdir.

$\mathrm{Bu}$ araștırma retro pazarlama kavramını betimlemeyi, markaların retro pazarlama uygulamasını kullanarak oluşturduğu reklam filmlerinde tüketicilerine ne gibi mesajlar vermek istediklerini ve retro pazarlama kavramının tüketicilerin zihninde neleri hatırlattığını ortaya koymayı amaçlamaktadır. Bu amaçla yapılan çalışmada, Tadım kuruyemiş markasının dünyada ve Türkiye'de popülaritesi her geçen gün artan Youtube üzerinden yayınlanan 'Türkiye'nin En Büyük Sosyal Ağı' adlı reklam filmi göstergebilimsel yöntemle analiz edilmiștir.

Anahtar Kelimeler: Halkla İlişkiler, Retro, Retro Pazarlama, Nostalji, Reklam. 
Research Article

\title{
Review of The Advertising About Tadim Nuts Brand From Retro Marketing Perspective With Semiotic Analysis Method
}

\author{
Murat Toksarı (Assoc. Prof. Dr. )
}

Sivas Cumhuriyet University Faculty of Communication

mtoksari@cumhuriyet.edu.tr

Amine Feyzanur Aydar (MA Student)

iD Sivas Cumhuriyet University Institute of Social Sciences feyzanuraydar@gmail.com

Date Received: 23.03.2021

Date Accepted: 28.06.2021

Date Published: 30.07.2021

https://doi.org/10.17680/erciyesiletisim.901504

\section{Abstract}

In today's competitive world it is very important for all business that wants to create a brand perception in the minds of consumers to develop strategies which will create a strong bond between the brand and the consumer. It is very important to give the right message in today's world where brands imitate each other and exaggerated advertisements are quite abundant, advertisements intended to entertain consumers rather than the desired message are proliferated and consumer habits are changing. For these reasons, leaving an emotional impact on consumers, reminding some of the past pleasures habits and blending them with the brand and presenting them through media tools have increased the importance of retro marketing concepts for businesses.

This research aims to describe the concept of retro marketing, what kind of messages the brands want to give to their consumers in the commercials they create using the retro marketing application, and what the concept of retro marketing reminds in the minds of consumers. In the study conducted for this purpose, Tadım nuts brand's advertising film named Turkey's Largest Social Network which was issued through Youtube whose popularity in the world and in Turkey is ever increasing was analyzed by semiotic method.

Keywords: Public Relations, Retro, Retro Marketing, Nostalgia, Advertising. 


\section{Giriş}

Geçmiş dönemlerde tüketicilerin satın alma davranışını pozitif yönde ya da negatif yönde etkileyen birçok unsur olmuştur. Bu dönemlerde işletmeler, kültürel, sosyal, kişisel, psikolojik ve psikografik faktörlere göre tüketicileri homojen gruplara ayırmaktaydı ve medya araçları vasıtasıyla mesajlarını iletmekteydi. Ancak 2000'li yıllardan sonra internetin insanların hayatının her noktasında olması ile birlikte tüketiciler daha çok bilinçlenmiş ve marka algıları farklılaşmıştı. Dünyanın herhangi bir noktasında yaşayan insanları, ağızdan ağıza iletişim kurarak ikna etmek işletmeler için oldukça güç olmuştur. $\mathrm{Bu}$ kapsamda işletmeler, marka mücadelelerinin yoğun olduğu günümüz dünyasında tüketicilerin beklentilerine nasıl cevap verebileceklerini ve duygularına nasıl hitap edebileceklerini belirlemeye yönelik stratejiler geliştirmişlerdir.

İşletmeler geliştirmiş oldukları stratejilerle, yoğun mesajlara maruz kalan ve duygusal karmaşa yaşayan tüketicilere ulaşmış, tüketicilerin algılarında yer edinmiş ve tüketiciler nezdinde marka farkındalıklarını artırmak için mesaj içeriklerini oluştururken çok titiz davranmışlardır. Özellikle markaların birbirlerini taklit ettiği, abartılı reklamların oldukça fazla olduğu, verilmek istenen mesajdan ziyade tüketicileri eğlendirmeye yönelik reklamların çoğaldığı ve tüketici alışkanlıklarının değiştiği günümüzde doğru mesajı vermek oldukça önemlidir. Bu sebeplerle tüketicilerde duygusal etki bırakmak, geçmişteki bazı hoşnut oldukları alışkanlıkları hatırlatmak ve bunu marka ile harmanlayarak medya araçları vasıtasıyla sunmak retro pazarlama kavramının işletmeler için önemini daha fazla artırmıştır.

İşletmeler retro pazarlamayı etkin kullanarak, tüketiciler ile marka arasında duygusal bağ oluşturarak, marka sadakatini artırmayı amaçlamaktadır. Bu amacı gerçekleştirmek isteyen markaların, nostaljik pazarlama sürecini hem ürünün tasarım aşamasında hem de mesajların sunulması aşamasında yapması gerekmektedir. Aynı zamanda işletmelerin, tüketicilerin nezdinde marka algılarını konumlandırmak istemesi, tüketicilerin ise geçmişlerindeki alışkanlıkları ile marka arasında duygusal bağ kuracak mesaj içeriklerine daha fazla ilgi göstermesi retro pazarlamanın önemini çok daha fazla artırmaktadır. Artık günümüz dünyasında işletmeler, retro pazarlama stratejileri ile tüketicilerin ihtiyaçlarını karşılayıp duygusal bir doyuma ulaşmayı hedeflemektedir. Bunu başarabildikleri ölçüde tüketiciler nezdinde markalarının farkındalığını olușturarak marka sadakatini sağlayabilirler.

Bu çalışma iki kısımdan oluşmaktadır. Çalışmanın ilk kısmında nostalji kavramı ve retro pazarlama kavramı genel bir çerçevede irdelenmiştir. Ayrıca gerek ülkemizde gerekse ülke sınırları dışında retro pazarlama ile ilgili reklam örnekleri incelenmiştir. Araştırmanın ikinci kısmında, zihinsel ve duygusal yönden tüketicilere geçmişi çağrıștıracak mesaj içeriği oluşturan Tadım kuruyemiş reklamının tüketicilerin subliminal algılarında ne yönde etki bıraktığını öğrenme durumu göstergebilimsel yöntemle kare kare analiz edilmektedir.

\section{Nostalji Kavramı}

Nostalji, insanların geçmişe duydukları özlem olarak ifade edilmekte olup işletme yönetimlerinin hem retro pazarlama stratejilerini belirlerken hem de retro marka algısını oluştururken mesaj içeriklerinde başvurdukları önemli temalardan biridir. 
Nostalji kavramı evlerinden uzakta savaşan İsviçreli paralı askerler arasındaki fiziksel ve psikolojik semptomları tanımlamak için Doktor Johannes Hofer (1688/1934) tarafından icat edilmiştir (Hepper, Timothy, Sedikides, \& Wildschut, 2011, s. 114).

Nostalji, eve ya da yurda dönüş anlamı taşıyan 'nostos' acı çekmek ve üzüntü duymak anlamına gelen 'algos' kelimesinin birleşiminden oluşmaktadır (Holbrook, 1993, s. 245). Nostalji, geçmişe dönerken yaşanılan bir duygudur ve insanların hayatında önemli rol oynayan bir şeye veya birine duyulan duygusal arzudur (Gajanova \& Vidrová, 2020, s. 42). Davis (1979) nostalji kavramını, şimdiki durumuna veya yaklaşan duruma yönelik bazı olumsuz duygular bağlamında yaşanmış bir geçmişin olumlu tonda çağrıştırılmasıdır şeklinde ifade etmiștir (Grębosz \& Pointet, 2015, s. 120).

Nostalji, özlem duygusuyla da ilişkilendirilmektedir. İnsanlar, kendi geçmişleri için veya kendi deneyimlerinin bir parçası olmayan diğer zamanlar için nostaljik bir his yaşayabilirler (Toledo \& Lopes, 2016, s. 36).

\section{Retro Pazarlama}

Retro; İngilizce bir kelime olmakla birlikte retrospective kelimesinden gelmektedir. Türkçe de ise "geçmişe dair her șey" anlamına gelmektedir (nedir.com, 2020). "Retro" kelimesi Latince'den türemiştir ve "geriye, arkaya" ve ayrıca "eskiden, geçmiş zamanlarda" anlamına gelmektedir (León-Bravo, Moretto, Cagliano, \& Caniato, 2019, s. 1054). Brown (1999, s. 365), retro kelimesini repro, retro, repro-retro olarak üç başlığa ayırmış, repro kavramını, eskiyi olduğu gibi çoğaltmak olarak ifade etmiş, retro kavramını, eskiyi yeniyle, genellikle eski tarz stil ve yüksek teknolojiyi birleștirme olarak ifade etmiş, reproretronun ise nostaljiden başlayarak gelişmiş ürünler anlamına geldiğini ifade etmiştir.

Aslında retro, geçmişi içeren ve bunlarla ilişkili deneyimleri hatırlatan bir kavram olarak bilinir. Retro yalnızca geçmiş olaylarla ilişkilendirilmez, aynı zamanda geçmişin geleceğe nasıl bağlanacağını ima eder (Yücel, Yücel, Gür, \& Gündüz, 2020, s. 79).

Hemen hemen her alanda insanların karşısına çıkan retro kavramı, geçmişe olan arzunun pazarlama alanında kullanılmasıdır. Retro kavramı ile pazarlama arasındaki ilişki, geçmiş dönemlerde kullanılan ürün ve hizmetlerin günümüze kadar taşınması olarak ifade edilmektedir (Demir, 2008, s. 32).

Retro pazarlama ise, işletmelerin önceki dönemlerde tüketicilerine sunduğu ürünler için eski veya nostaljiye dayalı bir marka kimliği oluşturmayı içerir (O’Brien, 2018; Gajanova \& Vidrová, 2020, s. 42).

Retro pazarlama, modern bir ürünü daha çekici hale getirmek için geçmişe yönelik nostaljiyi kullanmakla ilgilidir. Retro pazarlama sadece yaşlılar için geçmişe dönme fırsatı değil, aynı zamanda genç nesiller için bilinmeyen bir geçmişin resmini veren bilgi aracı olarak düşünülmektedir (Hatten, 2018, s.354; Holotová, Kádeková, \& Košıčiarová, 2020, s. 150)

Nostalji kavramıyla iç içe olan retro pazarlama, unutulmaya yüz tutmuş markaların tekrar canlanmasını sağlamaktadır (Marketing Türkiye, 2020). Bu bağlamda tüketicilerde duygusal bir his oluşturarak var olan pazarlama uygulamalarına " eski güzel günleri" hatırlatma amacı taşımaktadır. Retro pazarlama yoluyla ürün ve hizmetleri tasarlayan işletmelerin amacl, geçmişin popüler biçimlerini günümüze uyarlamak ve tüketicilerin nostaljik anılarını canlandırmaktır (Merlo \& Perugini, 2015, s. 94). 
Retro pazarlama ile ilgili gerek ülkemizde gerekse ülke sınırları dışında birçok reklam örneği ile karşılaşmak mümkündür.

Türkiye'de yapılan retro pazarlama alanındaki reklamlara örnek olarak Alo markasının 40. Yılında Zeki Müren ile tekrar bir araya gelmesi verilebilir. Alo markasının sponsorluğunda 0 Ses Türkiye yarışmasında yayınlanan özel bölümde, Zeki Müren'in hologram teknolojisi ile sahnede yer alması sağlanmıştır. Retro pazarlamanın her yaştan tüketiciyi aynı ortamda buluşturan alo reklamı, Zeki Müren'in kendi sesinden ve görüntüsünden dinlenilen 'Sana Alo Diyorum' şarkısı izleyicilere duygusal anlar yaşatmıştır (TheBrandAge, 2020).

Migros ticaret A.Ş. retro pazarlama stratejisini kullanarak oluşturduğu proje kapsamında 57. yılına özel markaların geçmişte kullandıkları ambalaj tasarımlarını ve fiyatlandırma sistemlerini günümüz perakendecilik koşullarına uyarlayarak tüketicilerine nostaljik bir şölen hazırlamıştır. Yapılan çalışma kapsamında geçmiş dönemlerde Migros markasını temsil eden satış kamyonu tüketicilerin karşısına yeniden çıkarılmıştır (Yazete, 2011)

Retro pazarlamaya göre yapılmış bir diğer reklam örneği Fruko markasına aittir. Sevimli bir çocuk aktör tarafından “ on yüz milyon baloncuk yuttum” sözleriyle 1989 yılında oluşturulan reklam filmi, küçükten büyüğe herkes tarafından beğeni toplamıştır. 14 yıl sonra aynı çocuk aktörün, büyümüş haliyle aynı reklam filminde oynaması tüketicilere geçmiş dönemleriyle buluşma imkânı sağlamıştır (Vatan Gazetesi, 2003).

Küresel markalar boyutunda retro pazarlamaya güzel bir örnek Coca-Cola Company'nin 2011 yılında 200'den fazla ülkede yapmış olduğu ve 125. yılını kutladığı etkinliktir. Coca Cola'nın kutlama stratejisini, geçmişi hatırlatan TV reklamı, dış mekân reklamları, çevrimiçi "Retro Poster Oluşturucu" ve paket içinde ikonik grafikler içermekteydi. CocaCola Company yapmış olduğu bu retro pazarlama çalışması ile, kalıcı cazibesini hayata geçirmek istemiş ve tüketicilere bir şişede mutluluk getirmeyi amaçlamıştır (Macleod, 2011; Grębosz \& Pointet, 2015, s. 122)

Hem ulusal boyutta hem de uluslararası boyutta retro pazarlama ile ilgili reklam filmlerinde verilmek istenen mesajların temel amacı, tüketicilerin zihinlerinde geçmișe yönelik özlem duygusunu canlandırmak ve reklamların çekildiği her karede tüketiciye nostaljik anlamda detaylar vermektedir. Bütün bu detaylar, tüketicilerde pozitif duygunun oluşmasının yanında markaya karşı sempatinin de oluşmasını sağlamaktadır.

\section{Araştırmanın Metodolojisi \\ Araştırmanın Amacı ve Kapsam}

Tüketicilerin markaya olan bağlılığını ve satın alma davranışlarını pozitif yönde etkilemek isteyen işletmeler, son dönemlerde marka farkındalığını oluşturmak için zihinsel ve duygusal anlamda tüketicilere geçmişi çağrıștıran mesaj içeriklerini kullanmaktadırlar. Markalar reklam filmlerini oluştururken belirli amaçlar doğrultusunda ilerlemektedir. $\mathrm{Bu}$ amaçlar, tüketicilerin dikkatini çekmek ve tüketicilerde satın alma davranışını pozitif yönde etkilemek olarak belirtilebilir.

Bu kapsamda araştırmanın temel amacı, zihinsel ve duygusal yönden tüketicileri geçmişe götürerek Retro pazarlama yapan Tadım kuruyemiş reklamının tüketicilerin subliminal algılarında ne yönde etki bıraktığını öğrenmeye yöneliktir. Araştırmanın amacı doğrultusunda, Tadım kuruyemiş markası ile ilgili yapılmış olan reklam filmi bütün yönleriyle incelenmiş ve göstergebilimsel yöntem ile analiz edilmiştir. 


\section{Çalışmanın Örneklemi}

Tadım kuruyemiş markası ile ilgili 14 Kasım 2014 tarihinde televizyonlarda ve Youtube' ta "Türkiye'nin En Büyük Sosyal Ağı" adı altında yayınladıkları reklam filmi örnekleme dahil edilmiş ve ilgili reklam filmi 15 Ocak 2021 - 2 Şubat 2021 tarihleri arasında günün belirli saatlerinde birçok kez izlenmiş ve reklam filminin her karesi göstergebilimsel yöntemle analiz edilmiştir. Çalışmanın örneklemi ve kısıtlılığı amaçsal örnekleme yöntemi ile belirlenmiștir. Bu bağlamda Türkiye'de yayınlanan Retro içerikli reklam filmleri incelenerek, Tadım kuruyemiş markasının reklam filminin yüksek izlenme sayısı ve nostaljiye yönelik zengin pek çok görsel ve dilsel göstergeye sahip olması çalışmanın amaçsal örneklemini oluşturmaktadır.

\section{Çalışmanın Yöntemi}

Markalar çeşitli pazarlama yöntemlerini kullanarak ve tüketicilerde marka sadakatinin oluşmasını sağlayarak rakiplerinden farklılaşmak isterler. Özellikle son dönemlerde markaların geçmişten günümüze vermek istedikleri mesaj tüketicilerin duygusal olarak etkileneceği Retro pazarlama stratejilerine göre yapılmaktadır. Çalışma kapsamında, reklam filminde kullanılan göstergelerin nasıl bir anlama sahip olduğunu ortaya koymak ve anlamları oluştururken hangi amaç doğrultusunda tüketicilere sunduğunu çözümlemek için, Tadım kuruyemiş markası ile ilgili reklam filmi göstergebilim yöntemiyle kare kare analiz edilmiştir.

Göstergebilimsel bir bakış açısı, hem sözlü anlam üreten hem de sözlü olmayan anlam üreten olayların yapılarını ve bunların altında yatan sistemi analiz eder (Mick, 1986, s. 197; Aurelie \& Roux, 2013, s. 50). Göstergebilimdeki temel ilkelerden biri, anlamın farklı olgular tarafından oluşturulması ve farklılığın, gösteren veya gösterilen arasındaki zitlık ile anlamlandırılmasıdır (Yan \& Ming, 2015, s. 59). Saussure ve Roland Barthes anlamlandırma sürecini iki farklı şekilde incelemektedir. Saussure anlamsal unsurları gösterge, gösteren ve gösterilen şeklinde ifade ederken, Barthes anlamlandırma sürecini düz anlam ve yan anlam şeklinde ele almaktadır (Turancı, 2021, s. 355). Bu bağlamda gösteren, gösterileni temsil eden metin, fotoğraf gibi fiziksel nesnelerin gösteriminden oluşmaktadır. Gösterilen fiziksel nesnelerin yansıttığı düşünce ve duyguların arka planında oluşturduğu anlamı ifade etmektedir. Gösterge ise, gösteren ve gösterileni barındıran ortak bir sentagmadır (Özel, 2008, s. 115). Umberto Eco (1976), göstergebilimin bir işaret olarak algılanabilecek her şeyi ilgilendirdiğini ifade etmiş ve işaretlerin basılı ve sözlü kelimelerden, görüntülerden, seslerden, jestlerden ve nesnelerden oluştuğunu belirtmiştir (Tsotra, Janson, \& Cecez-Kecmanovic, 2004, s. 4211). Roland Barthes, bütün izleyicinin aynı işaretleri algılamasını düz anlam olarak ifade ederken izleyicilerin işaretlerin altında yatan gizli anlamı yorumlamasını yan anlam olarak ifade etmektedir (Akerson, 2016, s. 102). Çalışma kapsamında incelenen Tadım kuruyemiş markasının izleyicilere sundukları düz anlamların yanında nostaljik duyguların ön plana çıktığı yan anlamların sunumu da gerçekleşecektir.

\section{Araştırmanın Bulguları}

Çalışma kapsamında Tadım kuruyemiş reklam filminin çekim ölçekleri dikkate alınarak kare kare analiz edilip anlamsal ifadeleri içeren gösterge, gösteren/düz anlam ve gösterilen/yan anlam şeklinde göstergebilimsel yöntem ile çözümlenmektedir.

Tadım “Türkiye'nin En Büyük Sosyal Ağı” Reklam Filminin Tanımı: 1971 yılından itibaren tüketicilerine hizmet veren Tadım markası, bilgisayarın ve internetin olmadığı dönemlerde sosyal ilişkilerin gerçek hayatta nasıl konumlandığını gösteren reklam 
filmi ile tüketicilerin karşısına çıkmıștır. Sosyal medya kavramlarını eğlenceli sahnelere dönüştüren Tadım markası, izleyicilere geçmiş dönemleri hatırlatarak özlem duygularının oluşmasını sağlayıp gülümsemelerine sebep olmuştur (Dijitalajanslar, 2014).

Kare 1

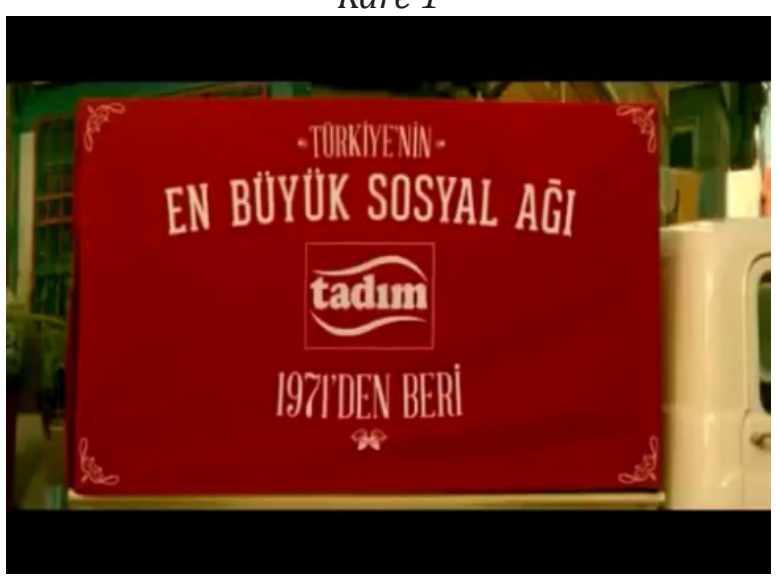

Kare 2

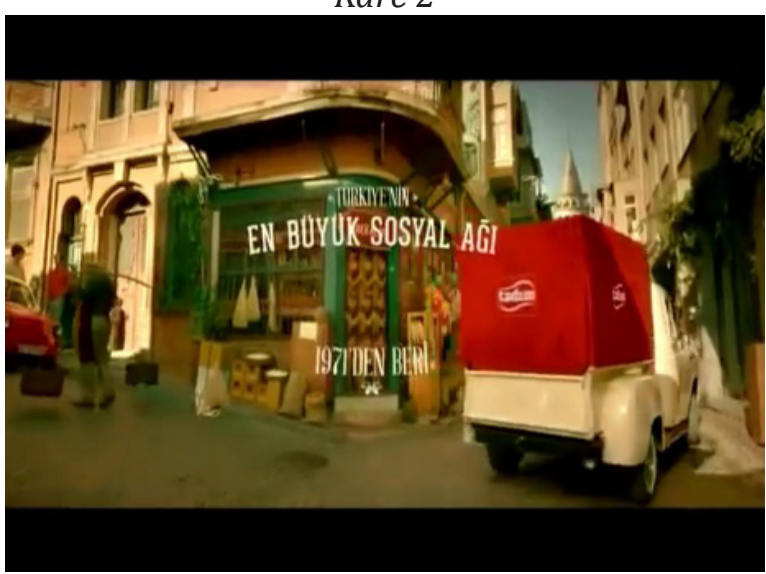

Kare 3

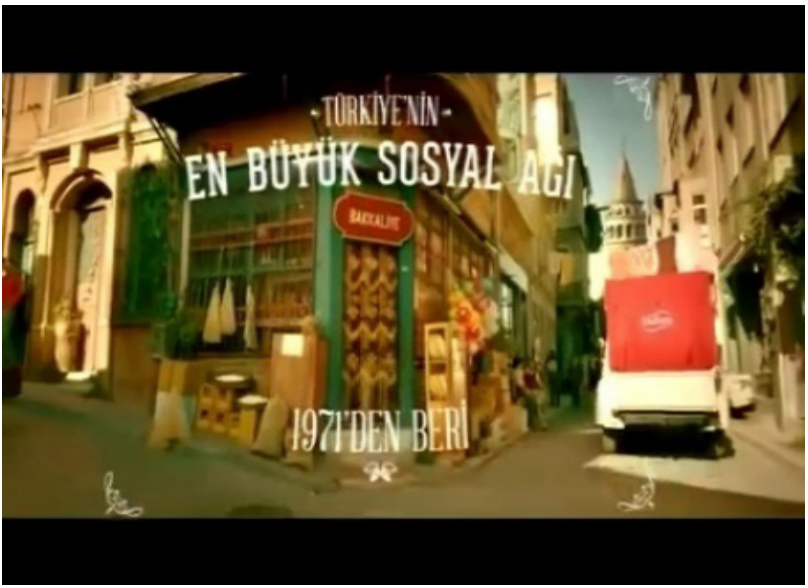

Şekil 1. Kare 1-2-3 Gösterge Analiz Tablosu

Kaynak: https://www.youtube.com/watch?v=3wHhVQ2hgYQ Yayınlanma Tarihi: 14 Kasım 2014

Tablo 1. Şekil 1'de Gösterilen Görsellerin Gösterge, Gösteren ve Gösterilen ile Çözümlenmesi

\begin{tabular}{|c|c|c|}
\hline Gösterge & Gösteren/Düz Anlam & Gösterilen/ Yan Anlam \\
\hline Nesne & $\begin{array}{l}\text { Eski döneme ait üzerinde Tadım } \\
\text { ambleminin olduğu kamyon }\end{array}$ & $\begin{array}{l}\text { Reklamda eski döneme ait kamyon modelinin } \\
\text { kullanılması, reklamın geçtiği dönem } \\
\text { hakkında izleyicilere bilgi vermektedir. }\end{array}$ \\
\hline İnsan & $\begin{array}{l}\text { Omuzundaki bakraçlar ile } \\
\text { yoğurt satan adam }\end{array}$ & $\begin{array}{l}\text { Emek gücünü, geçmiş dönemlerdeki ticaret anlayışını } \\
\text { ve insanların hayat mücadelesini göstermektedir. }\end{array}$ \\
\hline Nesne & Bakkaliye & $\begin{array}{l}\text { Birçok ürünün (süpürge, ekmek, top, yumurta } \\
\text { vb.) dışarıda olması insanların birbirlerine } \\
\text { olan güvenini göstermektedir. }\end{array}$ \\
\hline İnsan & $\begin{array}{l}\text { Sokağın her bir köşesinde } \\
\text { muhabbet eden insanlar }\end{array}$ & $\begin{array}{l}\text { Küçükten büyüğe, her yaş grubundan insanın dönemin } \\
\text { kılık kıyafetine uygun şekilde muhabbet etmesi } \\
\text { samimiyeti, dostluğu ve mutluluğu vurgulamaktadır. }\end{array}$ \\
\hline Nesne & $\begin{array}{l}\text { Sokakta karşılıklı iki evin } \\
\text { arasında ipe asılan çamaşırlar }\end{array}$ & Komşuluk/ Yardımseverlik \\
\hline Nesne & Park edilmiş eski model arabalar & $\begin{array}{l}\text { Reklamda geçmiş dönemleri çağrıştıran } \\
\text { figürlerin nasıl olduğunu göstermektedir. }\end{array}$ \\
\hline Nesne & Dönemin yapısına uygun evler & $\begin{array}{l}\text { Geçmiş dönemde insanların yaşam alanı olarak } \\
\text { kullandıkları evlerin mimari yapısını göstermektedir. }\end{array}$ \\
\hline
\end{tabular}




\begin{tabular}{|l|l|l|}
\hline Gösterge & Gösteren/Düz Anlam & Gösterilen/ Yan Anlam \\
\hline Yazııı & $\begin{array}{l}\text { Reklam filminin adının ve zamanın } \\
\text { belirtildiği ifade kullanımı }\end{array}$ & $\begin{array}{l}\text { Tanıtım/Yıl belirtilerek geçmişten günümüze kadar } \\
\text { gelmiş olan köklü bir marka olduğunu vurgulamaktadır. }\end{array}$ \\
\hline İşitsel & $\begin{array}{l}\text { Dış ses: Yıllar önce dijital } \\
\text { teknoloji yokken Türkiye'nin çok } \\
\text { büyük sosyal ağı mevcuttu }\end{array}$ & $\begin{array}{l}\text { Geçmişi ifade eden terimler kullanılarak, reklamın } \\
\text { geçmiş dönemi canlandırdığını ve izleyicilere } \\
\text { eski günleri hatırlattığını göstermektedir. } \\
\text { Geçmiş ile bugünü kıyaslamaktadır. }\end{array}$ \\
\hline
\end{tabular}

Şekil 1'de reklam filminin bu sahnesine kadar kullanılan göstergeler detaylı olarak incelendiğinde Zoom in/out (içe-dışa optik kaydırma) çekim açısı ile genel çekim ölçeği kullanıldığı görülmektedir. Bu durumun seyirciye reklamın geçeceği ortam hakkında ipucu verdiği görülmektedir. Tadım markası 'Türkiye'nin En Büyük Sosyal Ağı' bașlıklı reklam filminde kullandıkları göstergelerin geçmiş dönemlere ait olması, izleyicileri geçmişe yönelik bir yolculuğa çıkartarak eski günlerin hatırlanmasını sağlamaktadır. Çıkılan bu yolculukta geçmişin izlerine rastlanılmasıyla, seyircide geçmiş döneme yönelik özlem duygusunun zihinlerde canlanması amaçlanmaktadır.

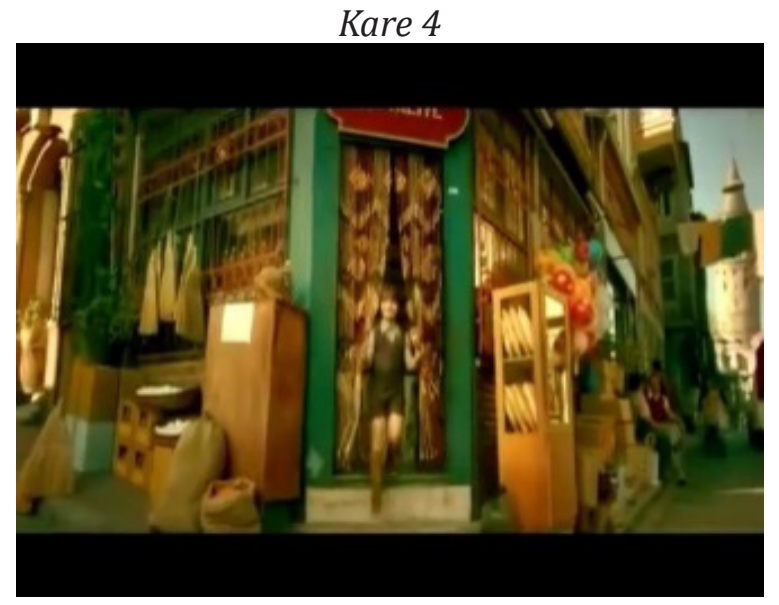

Kare 6

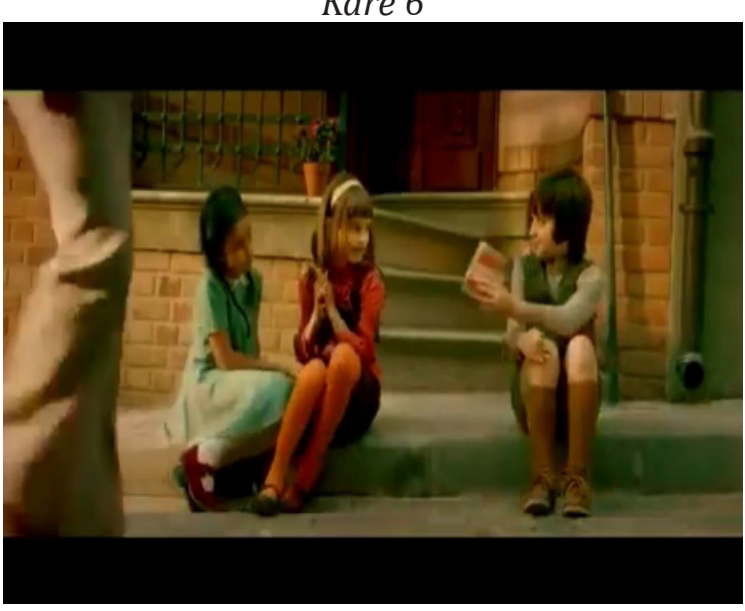

Kare 5

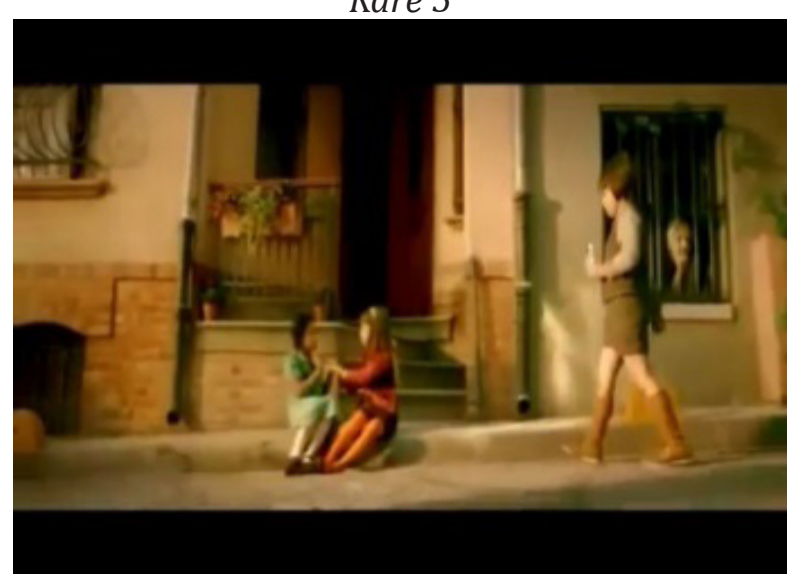

Kare 7

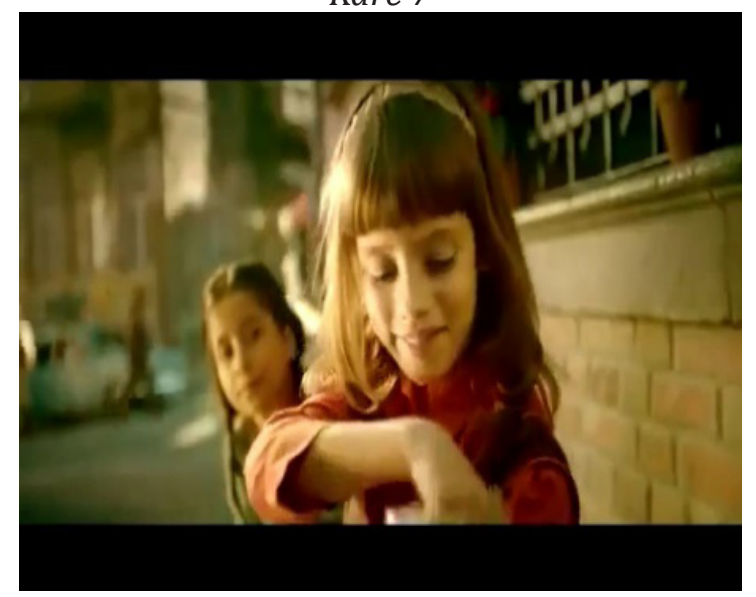




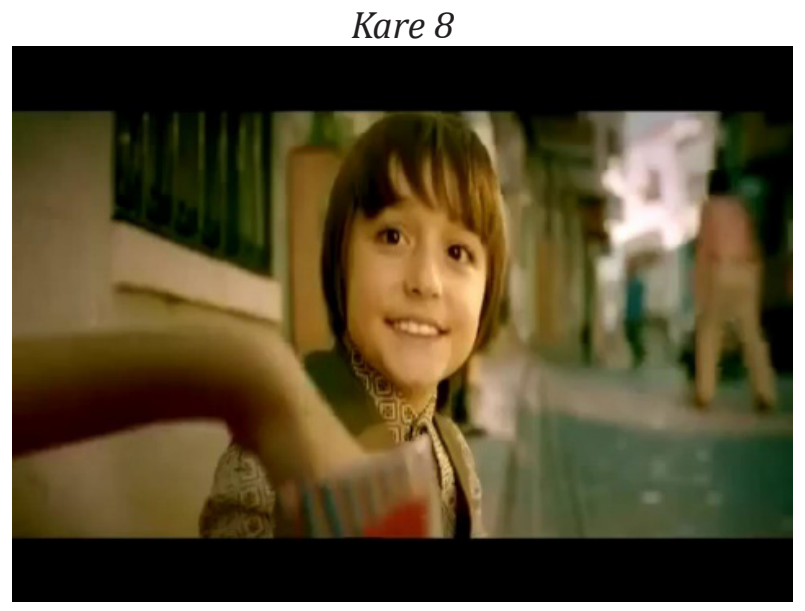

Sekil 2. Kare 4-5-6-7-8-Gösterge Analiz Tablosu

Kaynak: https://www.youtube.com/watch?v=3wHhVQ2hgYQ Yayınlanma Tarihi: 14 Kasım 2014

Tablo 2. Şekil 2'de Gösterilen Görsellerin Gösterge, Gösteren ve Gösterilen ile Çözümlenmesi

\begin{tabular}{|l|l|l|}
\hline Gösterge & Gösteren/Düz Anlam & Gösterilen/ Yan Anlam \\
\hline İnsan & $\begin{array}{l}\text { Kapı önünde süt } \\
\text { satan adam }\end{array}$ & $\begin{array}{l}\text { Geçmiş dönemlerde sokak sokak dolaşarak ev hanımlarının } \\
\text { istedikleri kilo kadar tencerelerine süt koyan satıcılar, eski } \\
\text { dönemlerde var olan ticari alışverişin bir göstergesidir. }\end{array}$ \\
\hline İnsan & Kaldırımda oturan üç çocuk & $\begin{array}{l}\text { Erkek çocuğun elindeki çekirdeği arkadaşlarına } \\
\text { uzatması paylaşımcılığın ve masumiyetin } \\
\text { göstergesi olarak ifade edilebilir. }\end{array}$ \\
\hline Nesne & $\begin{array}{l}\text { Evlerden aşağı iple } \\
\text { sarkıtılan ekmek sepeti }\end{array}$ & $\begin{array}{l}\text { Geçmiş dönemlerde üst katlarda oturan kişilerin sık sık } \\
\text { kullandığı ekmek alma yöntemi olup, mahalle bireylerinin } \\
\text { birbirleriyle arasındaki samimi ilişkiyi göstermektedir. }\end{array}$ \\
\hline Nesne & $\begin{array}{l}\text { Reklamda verilmek istenen mesaj, ürün yerleştirme } \\
\text { kullanılarak ürünün geçmişte sosyal ilişkiler kurulurken bireyler } \\
\text { arasında önemli bir bağ oluşturduğunu vurgulamaktadır. }\end{array}$ \\
\hline Dilsel & $\begin{array}{l}\text { Diş ses: "Mesela arkadaşlık } \\
\text { isteği böyle yapılırdı" }\end{array}$ & $\begin{array}{l}\text { Günümüzdeki arkadaşlık isteğiyle geçmişteki arkadaşlık } \\
\text { isteğini kıyaslayarak geçmişte nasıl yapıldığını göstermiştir. }\end{array}$ \\
\hline
\end{tabular}

Şekil 2'de giriş karesinde bakkaldan elindeki çekirdek paketiyle çıkan küçük erkek çocuğunun farklı yaş grubundaki kişilerle dolu bir sokak ortamına geçtiği bir sahne bulunmaktadır. Bu karelerde daha çok paylaşımcılığın, masumiyetin, birliğin ve samimiyetin vurgusu yapılmaktadır. Bununla birlikte geçmişi yansıtan detayların verilmesi de izleyicilerde nostaljik hissin oluşmasını sağlamaktadır. Reklam filminin 4-5-6-7-8. karelerinin olduğu sahne çekimleri incelendiğinde yüz, omuz ve boy çekim ölçeklerinden yararlanılarak 'Truck' kamera hareketi olarak bilinen sağa-sola kaydırmalı bir çekim açısından yararlanılmaktadır. Kullanılan çekim ölçekleri, izleyicilere anlam aktarımı sağlarken mimiklerin anlamı kuvvetlendirdiğini göstermektedir. 

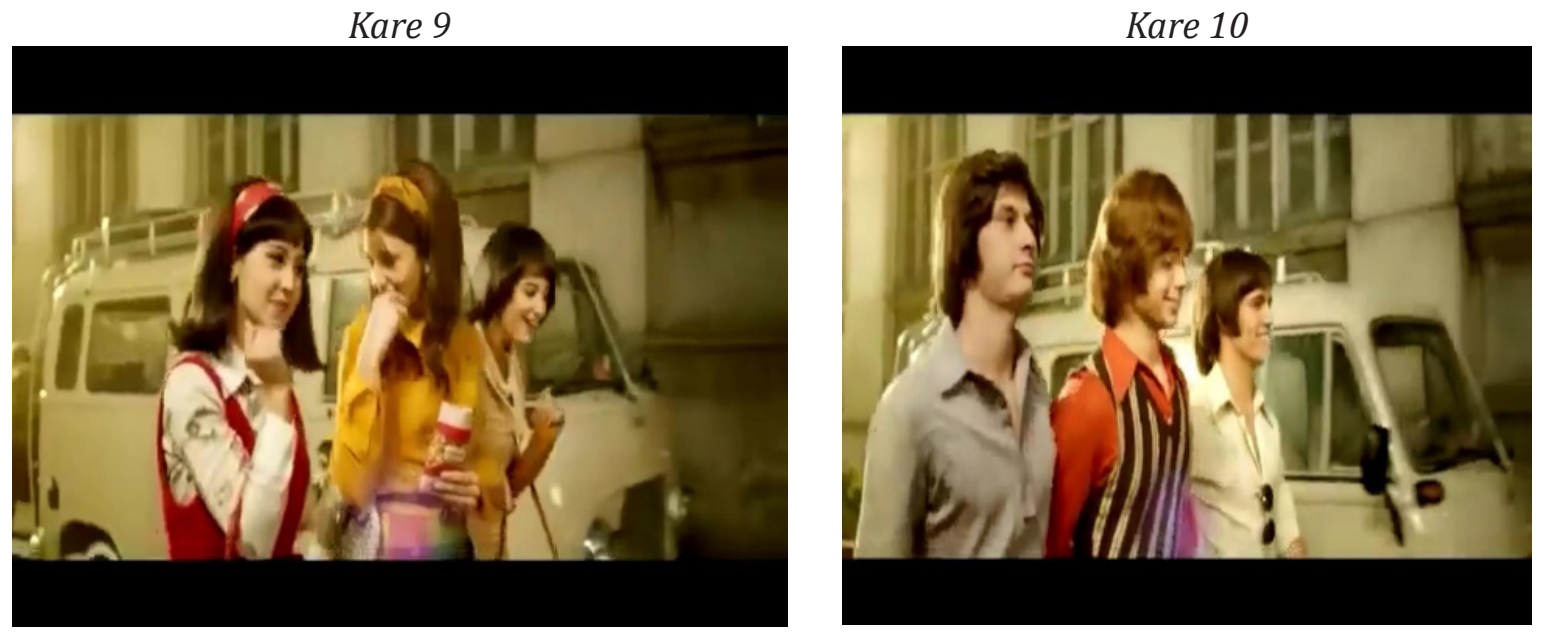

Kare 11

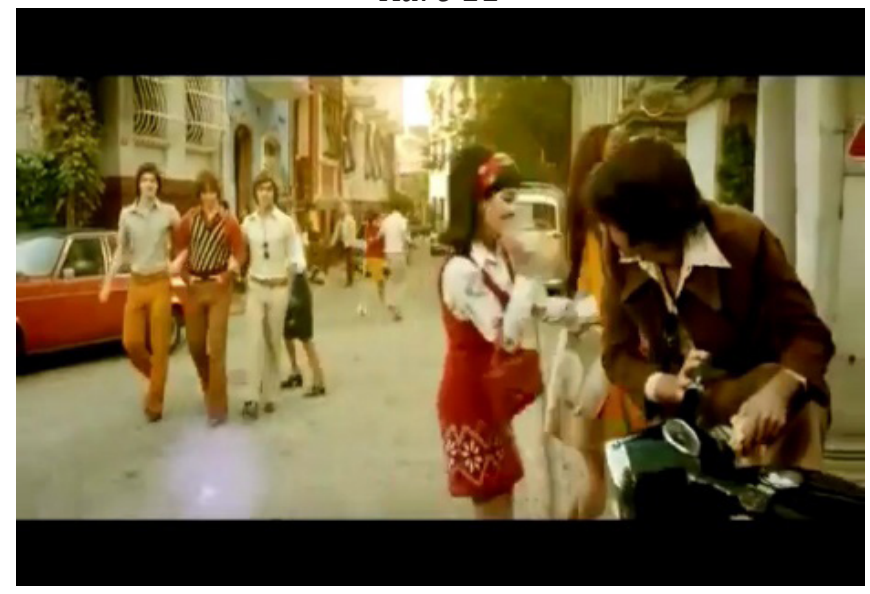

Şekil 3. Kare 9-10-11 Gösterge Analiz Tablosu

Kaynak: https://www.youtube.com/watch?v=3wHhVQ2hgYQ Yayınlanma Tarihi: 14 Kasım 2014

Tablo 3. Şekil 3'te Gösterilen Görsellerin Gösterge, Gösteren ve Gösterilen ile Çözümlenmesi

\begin{tabular}{|l|l|l|}
\hline Gösterge & Gösteren/Düz Anlam & Gösterilen/ Yan Anlam \\
\hline İnsan & $\begin{array}{l}\text { Üç genç kızı takip eden } \\
\text { üç genç erkek }\end{array}$ & $\begin{array}{l}\text { Geçmiş dönemlerde birini sevme, beğenme, } \\
\text { hoşlanma, nazlanma ve takip etme durumlarının } \\
\text { nasıl olduğunu göstermektedir. }\end{array}$ \\
\hline İnsan & $\begin{array}{l}\text { Sokakta yürüyen ve } \\
\text { muhabbet eden insanlar }\end{array}$ & $\begin{array}{l}\text { Farklı yaş grubundaki bireylerin samimi bir şekilde } \\
\text { sokakta yürüyerek sohbet etmesi durumu sokaktaki } \\
\text { canlılığı ve var olan sıcak ortamı göstermektedir. }\end{array}$ \\
\hline Nesne & Araba ve Motor & $\begin{array}{l}\text { Eski dönemlere ait araba ve motor modellerinin } \\
\text { geçmişte nasıl olduğunu göstermektedir. }\end{array}$ \\
\hline Nesne & Ayakkabı Boyacısı & Emek/ Maddi kazanç/Hayat Mücadelesi \\
\hline Dilsel & Kızların abilerine seslenmesi & Uyarı/ Naz yapmak \\
\hline Dilsel & $\begin{array}{l}\text { Dış ses: “ Takip etme ve takibi } \\
\text { bırakma çoktan bulunmuştu” }\end{array}$ & $\begin{array}{l}\text { Takip etme ve takibi bırakma durumlarının geçmiş } \\
\text { dönemlerde bulunduğu bu karede somut olarak gösterilmiştir. }\end{array}$ \\
\hline
\end{tabular}

Şekil 3'te normal açı içerinde yer alan üç genç kız önde yürürken hemen arkalarında onları takip eden üç genç erkek bulunmaktadır. Bu reklam karesinde, kızların abilerine seslenmesi ve abilerinin üç genç erkeğe bakmasıyla erkeklerin yollarını değiştirip geldikleri yöne doğru ilerlemesi gösterilmektedir. Genel anlamda bu sahnede yüz, omuz, boy ve genel çekim ölçeklerinin kullanılmasıyla bir kişiyi beğenmenin, o kişiyi sevmenin ve bunu karşı tarafa belli etmenin günümüze nazaran geçmişte nasıl olduğu beden dili ve mimikler ile gösterilmeye çalışılmaktadır. Kare kare analizin yapıldığı bu 
sahnede kullanılan Pan (sağa-sola açı hareketleriyle çevrinme) çekim açısı, diş sesin söylemi ile takip etme ve takibi bırakma kavramları oyuncular tarafından somut olarak gerçekleştiğini göstermektedir.
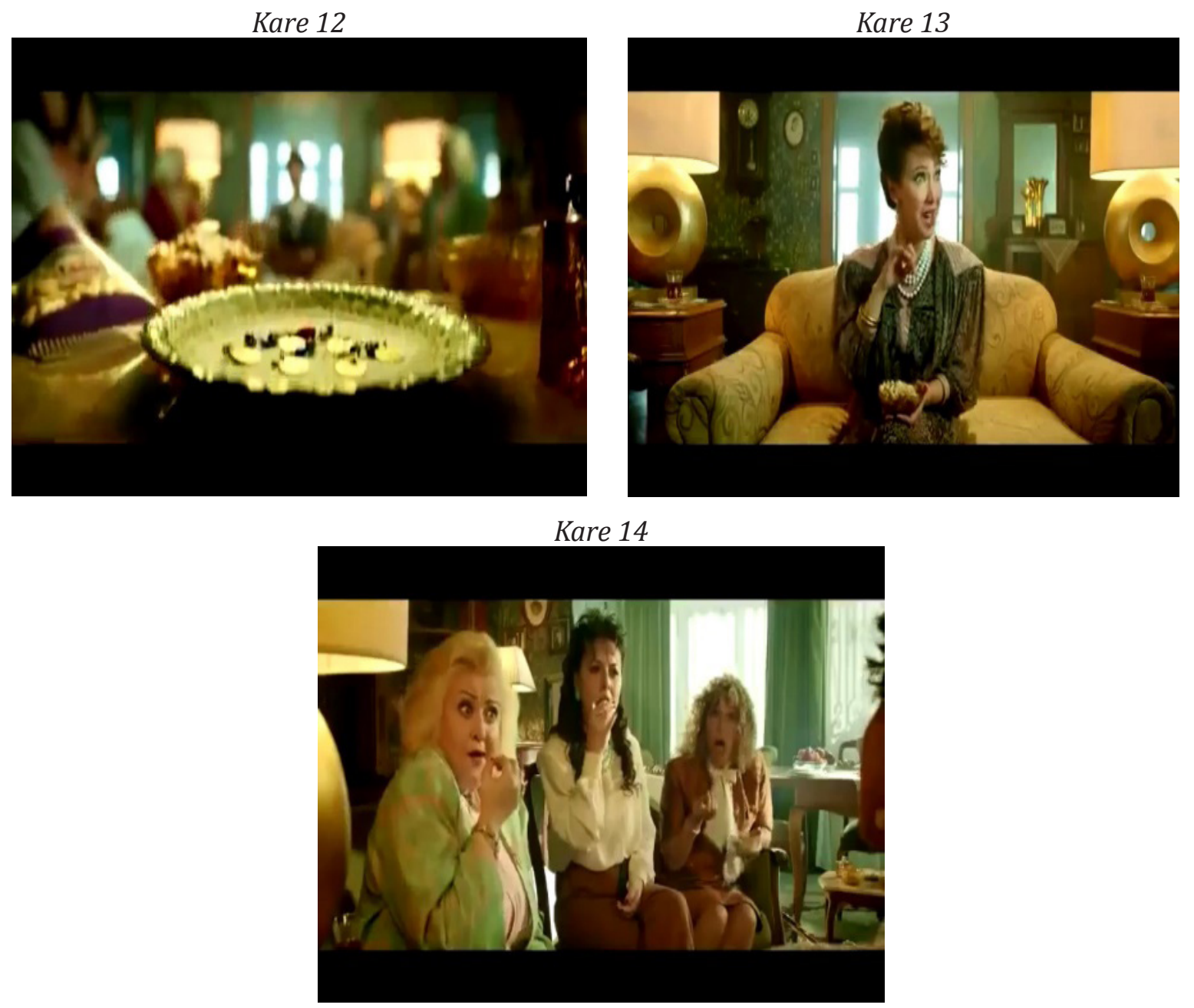

Şekil 4. Kare 12-13-14 Gösterge Analiz Tablosu Kaynak: https://www.youtube.com/watch?v=3wHhVQ2hgYQ Yayınlanma Tarihi: 14 Kasım 2014

Tablo 4. Șekil 4'te Gösterilen Görsellerin Gösterge, Gösteren ve Gösterilen ile Çözümlenmesi

\begin{tabular}{|l|l|l|}
\hline Gösterge & Gösteren/Düz Anlam & Gösterilen/ Yan Anlam \\
\hline Nesne & Tepsideki altınlar & Kadınların yaptığı altın gününü temsil etmektedir. \\
\hline İnsan & $\begin{array}{l}\text { Evin salon kısmında } \\
\text { oturan kadınlar }\end{array}$ & $\begin{array}{l}\text { Belirli bir konu üzerine toplanan kadınların sohbet } \\
\text { etmesi, anlatılanlara yönelik verdikleri tepkileri, yüz } \\
\text { ifadeleri ve ses tonları aralarında geçen muhabbete } \\
\text { ne kadar önem verdiklerini göstermektedir. }\end{array}$ \\
\hline Nesne & Ev Eşyaları & $\begin{array}{l}\text { Evdeki eşyaların kullanımı dönemin moda } \\
\text { zevkine göre tasarlanmıştır. Evdeki cansız } \\
\text { nesneler geçmişin izlerini çağrıştırmaktadır. }\end{array}$ \\
\hline Nesne & Tadım Kuruyemiş & $\begin{array}{l}\text { Sohbete eşlik eden kuruyemişleri, sahnenin birçok } \\
\text { noktasından izleyicilerin görmesi sağlanarak ortamdaki } \\
\text { muhabbetin sıcaklığı gösterilmeye çalışılmıştır. }\end{array}$ \\
\hline Dilsel & $\begin{array}{l}\text { Orta koltukta oturan } \\
\text { kadın: "Miras kalmış } \\
\text { ayol” demesi }\end{array}$ & $\begin{array}{l}\text { Samimi ev ortamında altın günü için toplanan } \\
\text { kadıların konuşmaları esnasında şaşırılacak bir bilginin } \\
\text { verilmesi, kadınların arasındaki muhabbet konusunun } \\
\text { hangi çerçevede olduğunu göstermektedir. }\end{array}$ \\
\hline
\end{tabular}




\begin{tabular}{|l|l|l|}
\hline Gösterge & Gösteren/Düz Anlam & Gösterilen/ Yan Anlam \\
\hline Dilsel & $\begin{array}{l}\text { Dış ses: "Her altın } \\
\text { gününde bir konu } \\
\text { Trending topic olurdu.” }\end{array}$ & $\begin{array}{l}\text { Kadınların toplanılan her altın gününde, } \\
\text { dikkatlerini çeken ve gündemlerin de olan bir } \\
\text { konu üzerinde konuştukları vurgulanmaktadır. }\end{array}$ \\
\hline
\end{tabular}

Şekil 4'teki reklam filminin karelerinde, evin salon bölümünde oturmakta olan yedi kadın kuruyemiş yerken sohbet etmektedir. Yüz çekim ölçeğinin bu sahnede kullanılması ortada oturan kadının anlattıklarına karşı diğer kadınların şaşkın ifadeler ile tepki verdiklerini izleyicilere göstermektedir. Karenin başında gösterilen tepsideki altınlar ve kuruyemişlerin olduğu sahne, ayrıntılı çekim ölçeğinin kullanılmasıyla kadınların altın gününde olduklarının göstergesi olup, bu günlerde kadınların kendi aralarında kurmuş oldukları samimi sohbet ortamına eşlik eden kuruyemişlere dikkat çekilmiştir. Aynı zamanda evde kullanılan eşyalar o dönemlere şahit olan izleyicilerin geçmiş dönemleri anımsamasını, o dönemleri bilmeyen genç nesillerin ise geçmiş dönemlerdeki ev tasarımlarının nasıl olduğunu görmelerini ve bilgi sahibi olmalarını sağlamıștır. Sahne girişinde alt açıdan üst açıya geçilen bir kamera hareketi varken sahne ortasında sağasola açı hareketleriyle oyuncuların gösterimini sağlayan Pan çekim açısının kullanıldığı görülmektedir.
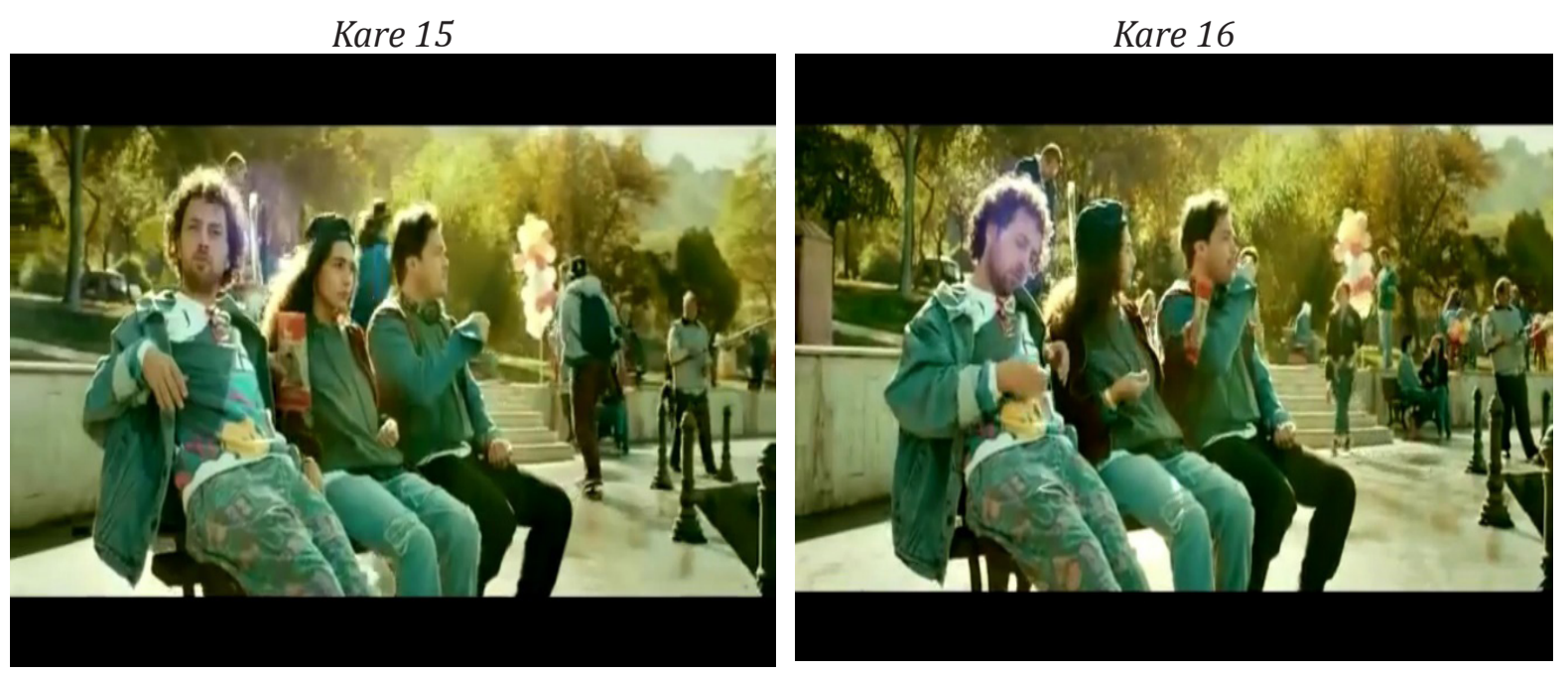

Şekil 5. Kare 15-16 Gösterge Analiz Tablosu

Kaynak: https://www.youtube.com/watch?v=3wHhVQ2hgYQ Yayınlanma Tarihi: 14 Kasım 2014

Tablo 5. Şekil 5'te Gösterilen Görsellerin Gösterge, Gösteren ve Gösterilen ile Çözümlenmesi

\begin{tabular}{|l|l|l|}
\hline Gösterge & Gösteren/Düz Anlam & Gösterilen/ Yan Anlam \\
\hline İnsan & Bankta oturan üç genç & $\begin{array}{l}\text { Etrafı izleyerek birbirlerini sırayla dürtüp çekirdek uzatan } \\
\text { gençlerin samimiyetini ve arkadaşlığını göstermektedir. }\end{array}$ \\
\hline İnsan & Balon satan adam & $\begin{array}{l}\text { Maddi kazancı, emek gücünü ve hayat } \\
\text { mücadelesini göstermektedir. }\end{array}$ \\
\hline Nesne & Park ortamı & $\begin{array}{l}\text { Yürüyüş yapan kişilerin, balık tutan kişilerin, paten kayan } \\
\text { çocukların ve bankta oturan insanların dikkatlerini farklı şeylerin } \\
\text { çektiği, aynı ortamda olsalar da bağımsız davrandıkları, her } \\
\text { birinin farklı yöne baktığı ve bulundukları ortamı ilgi alanlarına } \\
\text { göre pozitif yönde değerlendirdikleri vurgulanmaya çalışılmıştır. }\end{array}$ \\
\hline Dilsel & $\begin{array}{l}\text { Dış ses: "Kimse } \\
\text { kimseyi durup } \\
\text { dururken dürtmezdi" }\end{array}$ & $\begin{array}{l}\text { Reklam filmindeki karede, sosyal mecralardaki } \\
\text { dürtme seçeneği somut şekilde belirtilmiştir. }\end{array}$ \\
\hline
\end{tabular}

Şekil 5'teki bu karelerde ise kabalalığın olduğu bir park ortamında bankta oturan üç gencin birbirlerini dürterek çekirdek uzatması görüntülenmektedir. Karedeki gençlerin 
hiç konuşmadan birbirlerini dürterek çekirdek uzatmaları aralarındaki samimiyeti, arkadaşlığı, paylaşımcılığı ve dostluğu göstermektedir. Aynı zamanda dürtme kavramının sosyal mecraların dișında gerçek hayatta nasıl konumlandırıldığını ifade etmektedir. Kare kare analizin yapıldığı Şekil 5'te ise boy, genel ve ayrıntılı çekim ölçekleri kullanılmıştır. Normal açı içerisinde ele alınan bu sahne izleyicilere çekilen sahne ortamı hakkında detaylı bilgi aktarımını sağlamaktadır.
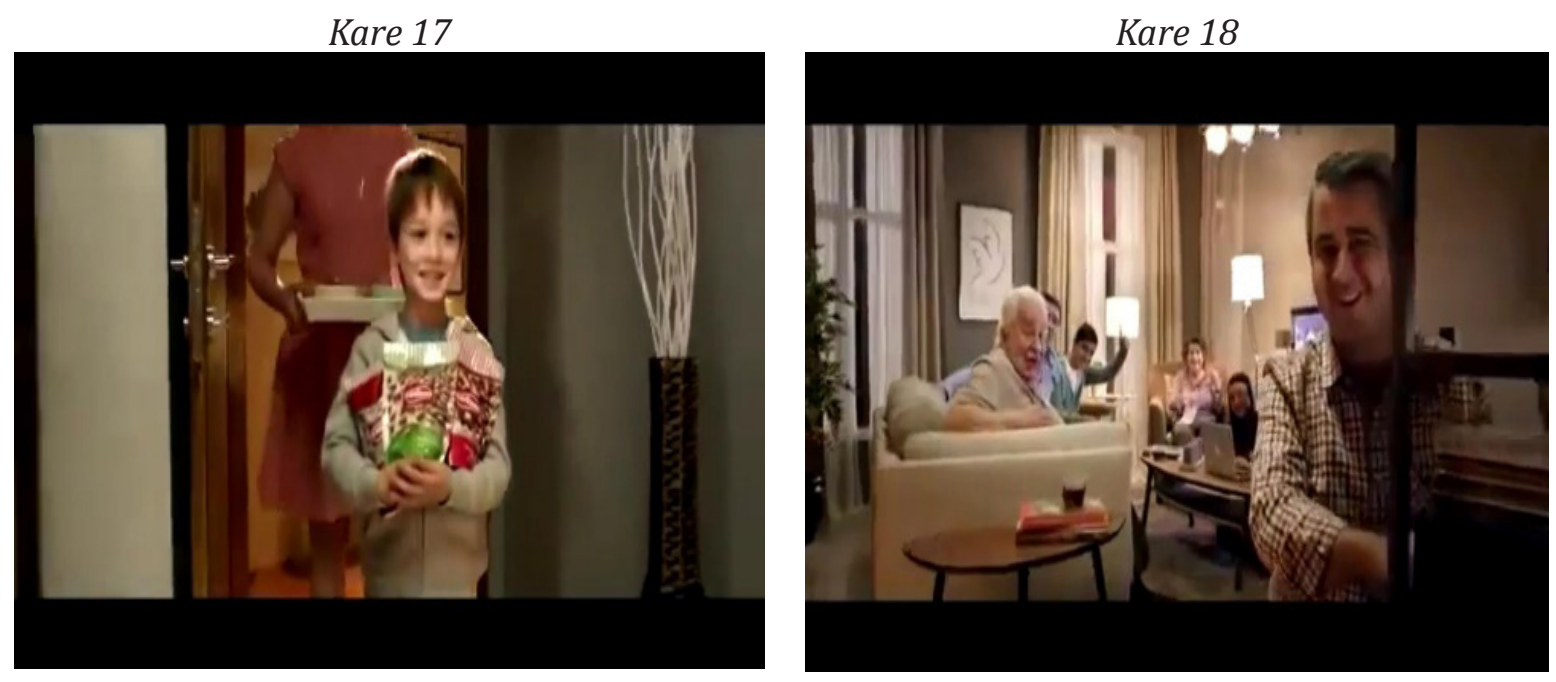

Kare 19

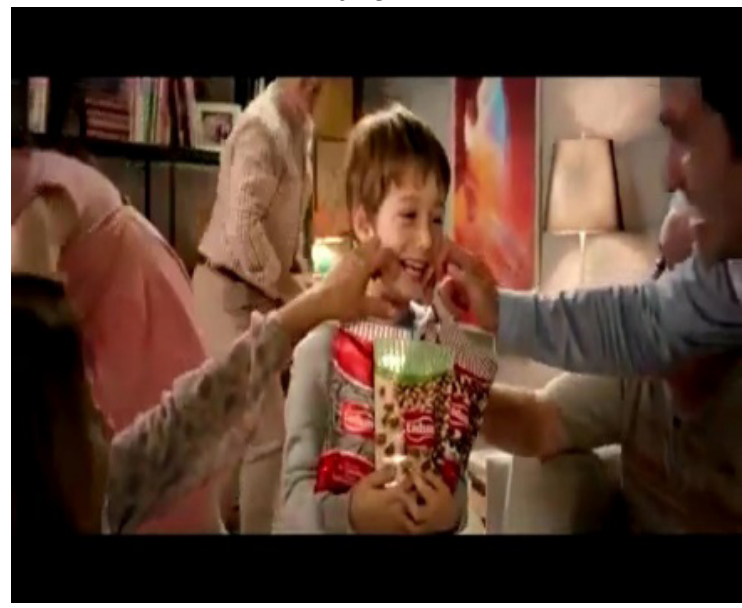

Şekil 6. Kare 17-18-19 Gösterge Analiz Tablosu

Kaynak: https://www.youtube.com/watch?v=3wHhVQ2hgYQ Yayınlanma Tarihi: 14 Kasım 2014

Tablo 6. Şekil 6’da Gösterilen Görsellerin Gösterge, Gösteren ve Gösterilen ile Çözümlenmesi

\begin{tabular}{|l|l|l|}
\hline Gösterge & Gösteren/Düz Anlam & Gösterilen/ Yan Anlam \\
\hline İnsan & $\begin{array}{l}\text { Evin salonunda oturan } \\
\text { aile bireyleri }\end{array}$ & $\begin{array}{l}\text { Küçükten büyüğe her yaş grubundan kişinin içinde } \\
\text { bulunduğu sıcak aile ortamı, paylaşımcılığın, mutluluğun, } \\
\text { sevginin, şefkatin ve ilginin göstergesidir. }\end{array}$ \\
\hline Nesne & Ev eşyaları & $\begin{array}{l}\text { Evin içindeki eşyaların kullanımı, günümüz moda } \\
\text { anlayş̧ına göre düzenlenmiştir. Bu durum geçmişe } \\
\text { ve günümüze vurgu yapıldığını göstermektedir. }\end{array}$ \\
\hline Dilsel & $\begin{array}{l}\text { Dış ses: Günümüzdeki } \\
\text { gibi Tadım ile ilgili bir } \\
\text { paylaşım olsa bu paylaşımı } \\
\text { herkes beğenirdi. }\end{array}$ & $\begin{array}{l}\text { Tadım markasının bilinen bir marka olması ve } \\
\text { herkes tarafından beğenilmesi, markanın popüler } \\
\text { olduğunu ve benimsendiğini göstermektedir. }\end{array}$ \\
\hline
\end{tabular}

Şekil 6'da reklam filminin bu karelerinde ise, annenin elinde kaselerin olduğu tepsi ile güler yüzlü erkek çocuğunun ise kucağında çeşitli tadım kuruyemiş paketleriyle 
kalabalık aile ortamının olduğu alana girmesi ve aile mensuplarının tamamının neșeli şekilde çocuğu ve anneyi karşılamaları gösterilmektedir. Günümüz koşullarına uygun çekilmiş olan bu kare izleyicilere gerek ev tasarımını gerekse aile bireylerinin giyim tarzını göstermektedir. Özellikle küçük erkek çocuğun aile tarafından ilgiyle karşılanması, sırtının okşanması ve yanaklarının sıkılması karşılıklı sevginin göstergesidir. Geçmiş ile günümüz arasında benzerliğin kurulduğu bu karede, markanın paylaşımcılık yönüne vurgu yapıldığını insanlara göstermektedir. Paylaşım temasına yoğunluk veren bu sahnenin belli bir bölümünde zoom çekim açısı kullanılmaktadır. 17-18-19. karelerin çekim ölçeklerine bakıldığında ise oturan aile bireylerine yönelik bel çekim ölçeğinden yararlanıldığı görülmektedir.

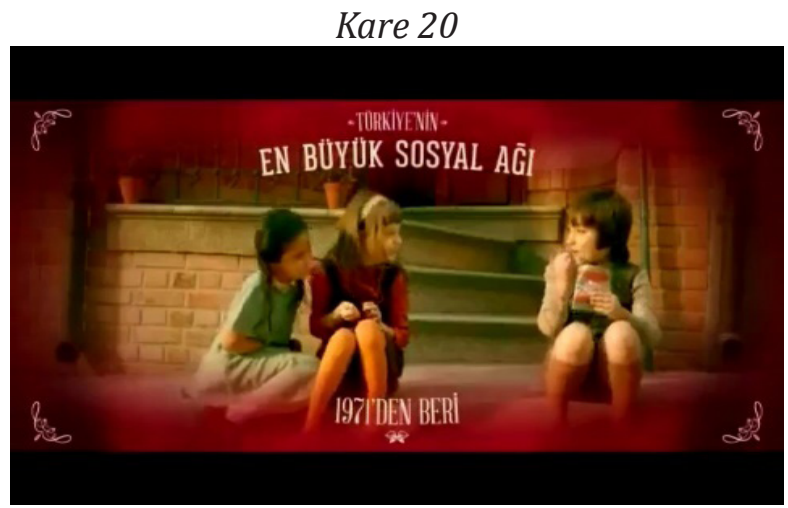

Kare 22

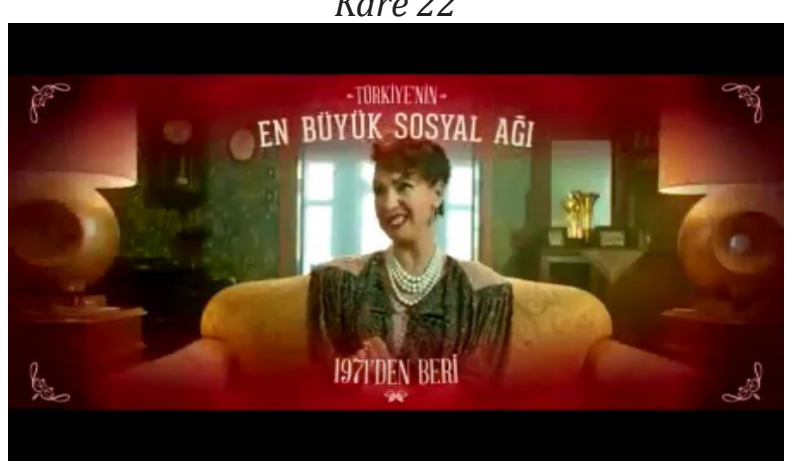

Kare 24

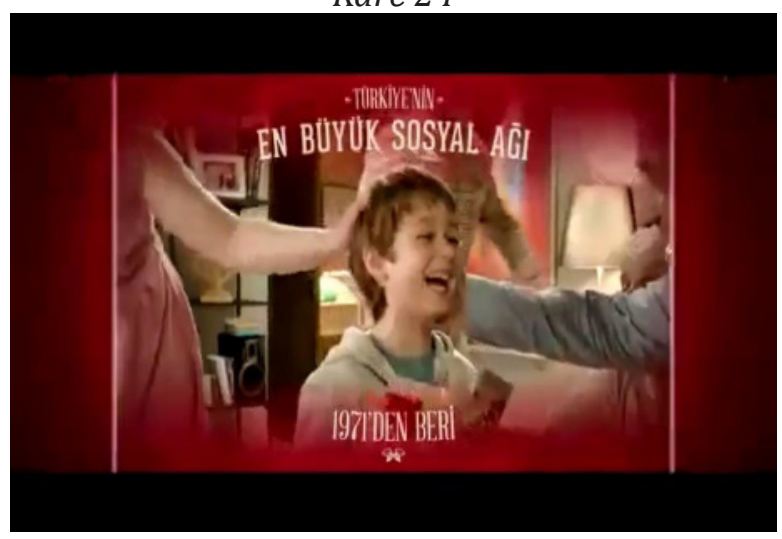

Kare 21

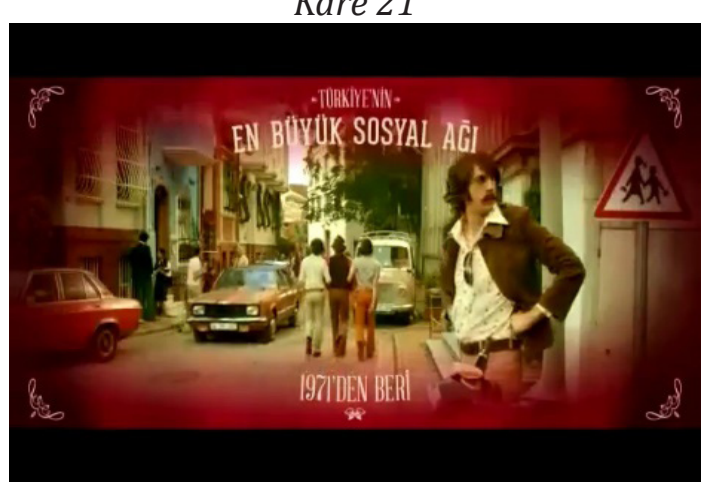

Kare 23

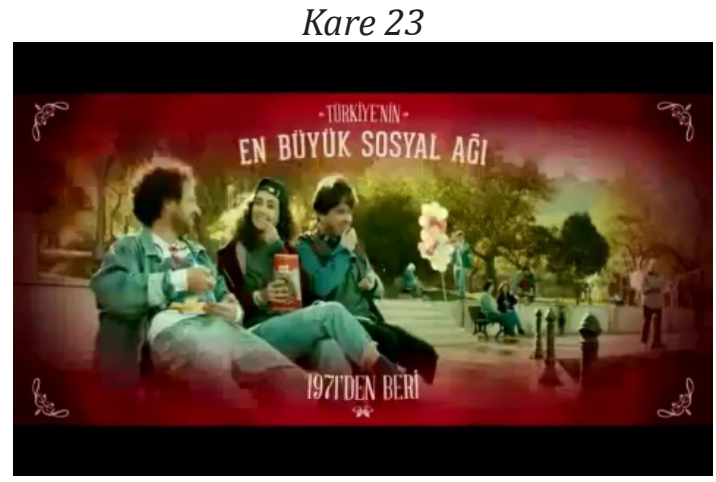

Kare 25

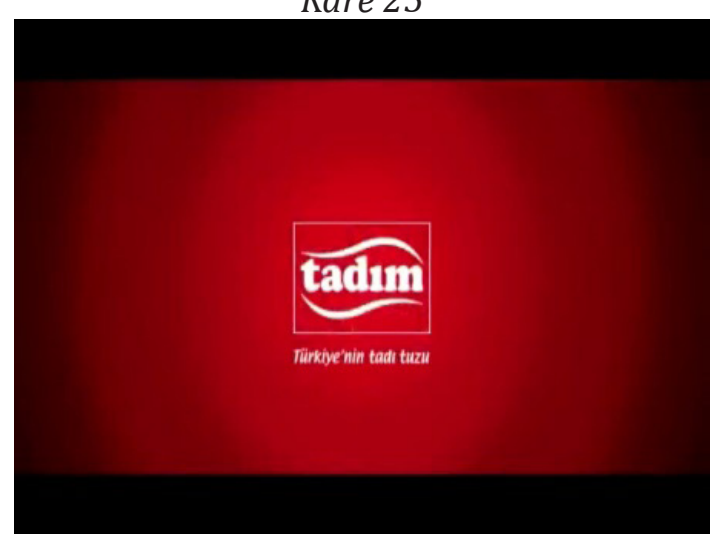

Şekil 7. 20-21-22-23-24-25 Gösterge Analiz Tablosu

Kaynak: https://www.youtube.com/watch?v=3wHhVQ2hgYQ Yayınlanma Tarihi: 14 Kasım 2014 
Tablo 7. Şekil 7'de Gösterilen Görsellerin Gösterge, Gösteren ve Gösterilen ile Çözümlenmesi

\begin{tabular}{|l|l|l|}
\hline Gösterge & Gösteren/Düz Anlam & Gösterilen/ Yan Anlam \\
\hline İnsan & $\begin{array}{l}\text { Reklam filminin tamamında } \\
\text { yer alan kişiler }\end{array}$ & $\begin{array}{l}\text { Sahne sonlarında oyuncuların sahneleri } \\
\text { gülümseme ile sonlandırması mutluluğu temsil } \\
\text { etmektedir. Bulundukları yer ise, paylaşımcılığı ve } \\
\text { sıcak sohbet ortamını ön plana çıkarmaktadır. }\end{array}$ \\
\hline Dilsel & $\begin{array}{l}\text { Dış ses: '1971' yılından başlayarak } \\
\text { günümüze kadar gelen süreçte } \\
\text { Türkiye'nin en büyük sosyal ağına } \\
\text { sahip tadım markası ile birlikte } \\
\text { insanların her anı muhabbet } \\
\text { dolu ve sevgi doludur. }\end{array}$ & $\begin{array}{l}\text { Tadım markasının geçmişten günümüze } \\
\text { insanları buluşturup sosyalleşmesine olanak } \\
\text { sağlayan bir marka olduğu vurgulanmaktadır. } \\
\text { Aynı zamanda lezzet ve keyif veren bir } \\
\text { marka olduğunun da göstergesidir. }\end{array}$ \\
\hline Yazılı & $\begin{array}{l}\text { Türkiye'nin En Büyük Sosyal } \\
\text { Ağı, 1971'den beri }\end{array}$ & $\begin{array}{l}\text { Yıl belirtilerek geçmişten günümüze kadar gelen } \\
\text { köklü bir marka olduğu vurgulanmaktadır. }\end{array}$ \\
\hline Yazılı & Tadım Türkiye'nin tadı tuzu & $\begin{array}{l}\text { Logo ve slogan aracılığıyla marka tanıtımı } \\
\text { sağlanmaktadır. Herkesin tercih ettiği mutluluk } \\
\text { veren marka olduğu vurgulanmak istenmiştir. }\end{array}$ \\
\hline
\end{tabular}

Şekil 7'de ayrı ayrı çekilmiş olunan sahnelerin normal açı ile devamlılı̆̆ı sağlanarak mutluluk kavramına dikkat çekilmiştir. Geçmişten bugüne geçişin sağlandığı reklam filmi, Tadım kuruyemiş markasının 1971 yılından günümüze kadar gelen süreçte tüketicilere hizmet veren köklü bir marka olduğunu ön plana çıkartmaktadır. Reklam verenin logosunun ve sloganının reklam filminin sonunda verilmesi, insanların subliminal algılarında markanın bilinirliliğini artırmakta ve markanın zihinlerde konumlanmasını sağlamaktadır. Reklam filminde verilmek istenen mesaj genel anlamda geçmişe vurgu yaparak izleyicilerde özlem duygusunu oluşturmakta ve geçmişten günümüze var olan paylaşımcılık kavramını ön plana çıkarmaktadır. Böylece Tadım markası, reklam filmi aracılığıyla paylaşımcılık duygusunu, mutluluğu, neşeyi, yaşama sevincini ön plana çıkararak, ailenin, arkadaşlı̆̆ın, samimiyetin ve dostluğun önemli olduğuna yönelik bir söylem olușturmaktadır.

\section{Sonuç ve Değerlendirme}

Rekabetin yoğun şekilde hissedildiği günümüz dünyasında markalar tüketicilere ulaşmakta zorlanmakta, işletme yöneticileri ise tüketicilere yönelik nasıl mesaj içeriği oluşturacakları konusunda ikileme düşmektedir. $\mathrm{Bu}$ nedenlerle son dönemlerde tüketicilerle doğru etkileşim kurmak isteyen işletmelerin, tüketiciler nezdinde pozitif etki bırakmak istemeleri ve kuşaklar arasındaki farklılıkları çok iyi analiz ederek zihinlerinde marka çağrıșımı oluşturmak istemeleri, nostaljik olaylarla markalarını entegre etmeleri ile sağlanabilir.

İşletmeler geliştirmiş oldukları stratejilerle, yoğun mesajlara maruz kalan ve duygusal karmaşa yaşayan tüketicilere ulaşmış, tüketicilerin algılarında yer edinmiş ve tüketiciler nezdinde marka farkındalıklarını artırmak için mesaj içeriklerini oluştururken çok titiz davranmışlardır. Özellikle markaların birbirlerini taklit ettiği, abartılı reklamların oldukça fazla olduğu, verilmek istenen mesajdan ziyade tüketicileri eğlendirmeye yönelik reklamların çoğaldığı ve tüketici alışkanlıklarının değiştiği günümüzde doğru mesajı vermek oldukça önemlidir. Bu sebeplerle tüketicilerde duygusal etki bırakmak, geçmişteki bazı hoşnut oldukları alışkanlıkları hatırlatmak ve bunu marka ile harmanlayarak medya araçları vasıtasıyla sunmak retro pazarlama kavramının işletmeler için önemini daha fazla artırmıştır.

Marka algısının her geçen gün değiştiği günümüz dünyasında rekabet avantajı kazanmak isteyen her işletmenin reklam mesajlarında retro içerik oluşturması ve geçmişe özlemi 
ifade eden sözcük, slogan, kullanılan eşya vb. bazı noktalara vurgu yapması tüketiciler ile marka arasında duygusal bağı daha artırmakta olduğunu göstermektedir. $\mathrm{Bu}$ kapsamda işletmeler markaları ile ilgili nostaljik pazarlama sürecini hem ürünün tasarım aşamasında hem de mesajların sunulması aşamasında yapmaktadırlar.

Çalışma kapsamında örnekleme dahil edilen Tadım markasının reklam filminde 1970'li dönemlere ait kıyafetler, gözlükler, arabalar, saç modelleri, bıyık modelleri, gibi bir takım vurgulayıcı öğelerin kullanıldığı ve bu reklam filminin tüketicileri geçmiş zamanda duygusal bir yolculuğa çıkardığı belirlenmiştir. Çalışma işaretleri anlamlandırma süreci olarak bilinen göstergebilimsel yöntem ile analiz edilmiștir. Her göstergenin ne anlama geldiği önceden belli olduğunu gibi, hangi anlamlarda kullanılacağı da bellidir. Fakat göstergeler bireylerin anlamlandırma ve yorumlama sürecinden geçtikten sonra dışarıya aktarılmaktadır. Bahsi geçen bu süreç ideolojik etmenleri, deneyimleri, içinde bulunulan sosyal çevreyi ve toplum yapısı içerisine almaktadır. Bu bağlamda örnekleme dahil edilen reklam filmi 25 kareye bölünerek 7 adet tablo içerisinde ele alınmıştır. Oluşturulan bu tablolar gösterge, gösteren(düz anlam) ve gösterilen(yan anlam) başlıkları temel alınarak okuyuculara sunulmuştur. Kare kare analiz yöntemi ile elde edilen göstergelerin teknik kodlar ile kültürel kodlar arasındaki ilişkisine bakılarak verilmek istenilen nostaljik mesajların çözümlenmesi yapılmıştır. İncelenen reklam filminde kullanılan kamera hareketleri çekim ölçekleri ve çekim açıları beden dilini ve mimik kullanımını kuvvetlendirecek niteliktedir. Örneğin şekil 2'de yer alan çocuk oyuncuların olduğu sahnede yüz çekim ölçeğinin kullanılması var olan paylaşımın masumiyet ile ilişsisine vurgu yapılırken şekil 4'te yer alan kadınların şaşkınlık ifadesine dikkat çekilmektedir. Yüz çekim ölçeğine ağırlık veren bir diğer kare ise şekil 6'da yer alan aile bireylerin yüzünde olan gülümsemedir. Mutluluğun bir göstergesi olarak ele alınan bu sahne, Tadım markasının aile bağını güçlendiren bir marka olunduğuna vurgu yapmaktadır. Ayrıntılı ve genel çekim ölçeklerinin sıklıkla kullanılması ise reklam filminin eski dönemleri hatırlatan dekor, aksesuar, kostüm gibi unsurlara dikkat çekilmesini sağlamaktadır. Genel anlamda bakıldığında mutluluğu, sevgiyi, paylaşımı, dostluğu, aileyi, birlik ve beraberliği ele alan sahnelerde oyuncuların içerisinde bulunduğu ortama uygun şekilde çekim ölçeklerine yer verildiği görülmektedir. 'Türkiye'nin En Büyük Sosyal Ağı' adlı reklam filminin ışık kullanımına bakıldığında şekil 5'e kadar olan sahnelerde kullanılan göstergeler ile birlikte sarı ışık kullanımı izleyicilerde geçmiş dönem izlenimi yaratırken şekil 6'da beyaz ışığın kullanımı ile günümüze geçiş vurgulanmaktadır. Reklam filminde dış sesin sahnelerle uyumu sağlanarak geçmiş zamanın vurgulandığı cümlelere (geçmiş dönemlerde dijital teknoloji ve internet yoktu) ve günümüze geçişin ifade edildiği cümlelere (ama tıpkı bugünkü gibi) sıklıkla yer verilmiştir. Tadım markasının reklam filminde retro pazarlamayı etkin kullanarak, izleyenlerin zihinlerinde eski günleri çağrıştırarak geçmiş ile bugünü bir araya getirmeyi amaçlamaktadır. Aynı zamanda zihinsel ve duygusal yönden tüketicileri etkilemeyi amaçlayan Tadım Kuruyemiş markası 'Türkiye'nin En Büyük Sosyal Ağı' adı altında yayınlanan reklamın birçok bölümünde 1971 tarihi vurgulanmış ve markanın köklü bir geçmişe sahip olduğu gösterilmek istenmiştir.

Markalaşma yolunda en iyisi olmak isteyen işletmelerin tüketicilerin dikkatini çekmeye yönelik olarak oluşturdukları nostaljik reklam senaryoları hem hedef kitleye doğru mesajın verilmesini hem de tüketicilerin markaya olan duygu yoğunluklarının artmasıyla marka farkındalığının oluşmasını sağlayacaktır. Tadım markası bu bağlamda, geçmişi çağrıştıran figürleri günümüze uyarlayarak tüketicilerin zihinsel ve duygusal bileşenlerini 
harekete geçirmekte ve tüketicilerin satın alma davranışlarını etkileyerek markaya olan bakış açılarını değiştirmede başarılı bir çalışma ortaya koymaktadır.

\section{Kaynakça}

Akerson, F. E. (2016). Göstergebilimine Giriş. İstanbul: Bilge Kültür Sanat.

Brown, S. (1999). Retro-marketing: yesterday's tomorrows, today! Marketing Intelligence\&Planning, 17(7), 363-376.

Demir, F. O. (2008). Pazarlamanın nostaljik oyunu: retro markalama. Ístanbul Üniversitesi İletişim Fakültesi Dergisi(33), 29-41.

Dijitalajanslar. (2014, Kasım 17). Tadım Türkiye’nin En Büyük Sosyal Ağı Reklamı. Mart 8, 2021 tarihinde www.dijitalajanslar.com: https://www.dijitalajanslar.com/tadimturkiyenin-en-buyuk-sosyal-agi-reklami/ adresinden alındı

Gajanova, L., \& Vidrová, Z. (2020). Retro marketing a phenomenon of modern times. Technology Transfer: Innovative Solutions in Social Sciences and Humanities(3), 4244.

Grębosz, M., \& Pointet, J.-M. (2015). The retro trend in marketing communication strategy of global brands. Journal of Intercultural Management, 7(3), 119-132.

Hepper, E., Timothy, D. R., Sedikides, C., \& Wildschut, T. (2011). Odyssey’s End: Lay Conceptions of Nostalgia Reflect Its Original Homeric Meaning. American Psychological Association, 12(1), 102-119. doi:10.1037/a0025167

Holbrook, M. B. (1993). Nostalgia and consumption preferences: some emerging patterns of con- sumer tastes. Journal of Consumer Research, 20(2), 245-256.

Holotová, M., Kádeková, Z., \& Košıčıarová, I. (2020). Retro marketıng - a power of nostalgıa which works among the audience. Communication Today, 11(2), 148164.

León-Bravo, V., Moretto, A., Cagliano, R., \& Caniato, F. (2019). Innovation for sustainable development in the food industry: retro and forward looking innovation approaches to improve quality and healthiness. Corporate Social Responsibility and Environmental Management, 26(5), 1049-1062.

Marketing Türkiye. (2020). Son zamanların gözde furyası "retro pazarlama. ARALIK 18, 2020 tarihinde https://www.marketingturkiye.com.tr/: https://www. marketingturkiye.com.tr/haberler/son-zamanlarin-gozde-furyasi-retropazarlama/ adresinden alındı

Merlo, E., \& Perugini, M. (2015). The revival of fashion brands between marketing and history. Journal of Historical Research in Marketing, 7(1), 91.

nedir.com. (2020). Retro nedir? Aralık 18, 2020 tarihinde www.nedir.com: https://www. nedir.com/retro adresinden alındı

Özel, Z. (2008). «Beynelmilel» : Bir Film Afişinin Göstergebilimsel Çözümlemesi. S. Parsal, \& S. Parsal (Dü.) içinde, Film Çözümlemeleri (s. 113-130). İstanbul: Multilungual.

TheBrandAge. (2020). Dosya Konusu - Son dönemin modası: Retro pazarlama. Aralık 27, 2020 tarihinde www.thebrandage.com: https://www.thebrandage.com/dosyakonusu-son-doenemin-modasi-retro-pazarlama adresinden alındı 
Toledo, A. C., \& Lopes, E. L. (2016). Effect of nostalgia on customer loyalty to brand postmerger / acquisition. BAR-Brazilian Administration Review, 13(1), 33-55. doi: 10.1590/1807-7692bar2016150007

Tsotra, D., Janson, M., \& Cecez-Kecmanovic, D. (2004). Marketing on the Internet: A Semiotic Analysis. Proceeding of the Tenth Americas Conference on Information Systems. New York.

Turancı, E. (2021). Kurumsal Sosyal Sorumluluk Bağlamında Modada Geri Dönüşüm ve Sürdürülebilirlik: Göstergebilimsel Bir Analiz. Erciyes İletişim Dergisi, 8(1), 347371.

Turancı, E. (2021). Kurumsal Sosyal Sorumluluk Bağlamında Modada Geri Dönüșüm ve Sürdürülebilirlik: Göstergebilimsel Bir Analiz. Erciyes İletişim Dergisi, 8(1), 347371.

Vatan Gazetesi. (2003, Mart 13). On yüzbin milyon baloncuk büyüdü. Aralık 29, 2020 tarihinde www.gazetevatan.com: http://www.gazetevatan.com/on-yuzbinmilyon-baloncuk-buyudu-6047-yasam/ adresinden alındı

Yan, S., \& Ming, F. (2015). Reinterpreting Some Key Concepts in Barthes' Theory. Journal of Media and Communication Studies, 3(7), 59-66.

Yazete. (2011). MIGROS'TA 50 YIL ÖNCESININ FIYATLARI... MIGGROS, TÜRKIYYE'DE KURULUSSUNUN 57. YILI DOLAYISIYLA ÜLKENİ. Aralık 29, 2020 tarihinde www.yazete.com: http://www.yazete.com/ajans/migros-ta-50-yil-oncesininfiyatlari-migros-turkiye-de-kurulusunun-57-yili-dolayisiyla-ulkeni-241072.html adresinden alındı

Youtube. (2014, Kasım 14). Tadım “Türkiye’nin En Büyük Sosyal Ağı”. Ocak 04, 2021 tarihinde www.youtube.com: https://www.youtube.com/ watch?v=3wHhVQ2hgYQ adresinden alınd

Yücel, N., Yücel, A., Gür, Y. E., \& Gündüz, K. (2020). Examınıng retro marketıng ads from the perspective of neuromarketing: the example of nestle brand. Erciyes Üniversitesi IIIBF Dergisi(55), 77-90. 


\title{
Review of The Advertising About Tadim Nuts Brand From Retro Marketing Perspective With Semiotic Analysis Method
}

\author{
Murat Toksarı (Assoc. Prof. Dr.) \\ Amine Feyzanur Aydar (MA Student)
}

\section{Extended Abstract}

In today's competitive world, it is very important for every business that wants to create a brand perception in the minds of consumers to develop strategies that will create a strong bond between the brand and the consumer. Especially with the intensive use of digital technology by people, the expectations of consumers have changed compared to the past, and as a result, businesses have made an intense effort to position themselves in consumers' minds. In this context, businesses have turned to message contents that cause emotional intensity in consumers' subliminal perceptions and developed strategies that focus on retro marketing.

Businesses aim to increase brand loyalty by using retro marketing effectively, creating an emotional bond between consumers and the brand. Brands that want to achieve this goal must do the nostalgic marketing process both in the design phase of the product and the presentation of the messages. At the same time, the fact that businesses want to position their brand perceptions in the eyes of consumers, and consumers show more interest in message content that will establish an emotional connection between the brand with their past habits, increases the importance of retro marketing much more. In today's world, businesses aim to meet the needs of consumers and achieve emotional satisfaction with retro marketing strategies. To the extent that they can achieve this, they can create brand loyalty by creating awareness of their brands in the eyes of consumers.

This research aims to describe the concept of retro marketing, what kind of messages the brands want to give to their consumers in the commercials they create using the retro marketing application, and what the concept of retro marketing reminds in the minds of consumers.

It has been very difficult for businesses to persuade people living in any part of the world by communicating word of mouth. In this context, in today's world where brand struggles are intense, businesses have developed strategies to determine how they can respond to consumers' expectations and address their emotions. With the development of digital technology, businesses that want to reach consumers who are exposed to intense messages and experience emotional turmoil and take a place in their perceptions are very meticulous while creating message content to increase the awareness of their brands. It is very important to give the right message in today's world where brands imitate each other, exaggerated advertisements are quite abundant, advertisements intended to entertain consumers rather than the desired message are proliferated and consumer habits are changing. For these reasons, leaving an emotional impact on consumers, reminding some of the past pleasure habits, and blending them with the brand and presenting them through media tools have increased the importance of retro marketing / retro advertising concepts for businesses. The study consists of two parts. In the first part, the concept of nostalgia and retro marketing concepts are discussed in a general framework and examples of retro marketing in our country and abroad are examined. In 
the second part, the effect of Tadım nuts advertisement which creates message content that reminds consumers mentally and emotionally the past on the subliminal perceptions of consumers and the learning situation were analyzed with semiotic method.

The results analyzed with the semiotic method were as follows;

- It has been determined that some highlighting elements such as clothes, glasses, cars, hairstyles, mustache models belonging to the 1970s were used in the commercial of the Tadım brand, and this commercial film took consumers on an emotional journey in the past.

- The Tadım brand aimed to bring the past and the present together by evoking the old days in the minds of the audience in the commercial.

- It has been determined that sentences emphasizing the past tense (years ago, when there were no computers and internet yet) and sentences expressing the transition to the present (but just like today) were frequently used in the commercial film by ensuring the harmony of the external voice with the scenes.

- Tadım nuts brand has wants to emphasize that the brand has a deep-rooted history by highlighting the 1971 history in many parts of the advertisement which was issued under the name of Turkey's Largest Social Network.

In this context, Tadım brand adapts past figures to the present, activates the mental and emotional components of the consumer, and demonstrates a successful work in changing consumers' perspectives on the brand by influencing their buying behavior.

Keywords: Public Relations, Retro, Retro Marketing, Nostalgia, Advertising.

Bu makale intihal tespit yazııımlarıyla taranmıştır. Intihal tespit edilmemiştir.

This article has been scanned by plagiarism detection softwares. No plagiarism detected.

Bu çalışmada "Yükseköğretim Kurumları Bilimsel Araştırma ve Yayın Etiği Yönergesi" kapsamında uyulması belirtilen kurallara uyulmuştur.

In this study, the rules stated in the "Higher Education Institutions Scientific Research and Publication Ethics Directive" were followed.

Yazarların çalışmadaki katkı oranları eşittir.

The authors' contribution rates in the study are equal.

Çalışma kapsamında herhangi bir kurum veya kişi ile çıkar çatışması bulunmamaktadır.

There is no conflict of interest with any institution or person within the scope of the study. 